\title{
Confirmation of association between the e4 allele of apolipoprotein E and Alzheimer's disease
}

\author{
M Liddell, J Williams, A Bayer, F Kaiser, M Owen
}

\begin{abstract}
The Apo E genotype of 86 patients with Alzheimer's disease (AD) and 77 age matched controls was determined by digestion of Apo E PCR products with the restriction enzyme $C$ fol. The frequency of the 4 allele was significantly increased in the patient group $(0.33)$ as compared with controls $(0 \cdot 12)$. This effect was seen in patients with a family history and in sporadic cases. The odds ratio in homozygotes for the e4 allele was $11 \cdot 24(95 \%$ confidence interval $2 \cdot 45-51 \cdot 50)$. There was no relationship between age of onset and Apo $E$ genotype. There was no linkage disequilibrium between the apolipoprotein E locus and a TaqI polymorphism at the Apo CII locus, and no allelic association between Apo CII and AD.
\end{abstract}

( Med Genet 1994;31:197-200)

Alzheimer's disease is the commonest cause of presenile and senile dementia. Its incidence increases with advancing age, such that by the ninth decade as many as $36 \%$ of people may be affected. Although the characteristic neuropathological changes are fairly uniform from case to case, the condition is aetiologically heterogeneous.

Most recent molecular genetic studies have focused upon early onset "familial Alzheimer's disease" (FAD) because its pattern of inheritance suggests simple autosomal dominant transmission. In some families FAD is associated with mutations within exons 16 and 17 of the amyloid precursor protein (APP) gene on chromosome $21^{1-4}$ and most of the remainder have been linked to a locus on the long arm of chromosome $14 .^{5-8}$ The so-called "Volga-German" FAD kindreds are not linked to either APP or chromosome 14,5 thereby implicating the existence of at least a third locus. Thus, even apparently genetically simple FAD is genetically heterogeneous.

The genetics of common, late onset, and sporadic $\mathrm{AD}$ is more complicated, and this disorder is almost certainly both aetiologically and genetically heterogeneous. Complex segregation analysis suggests the possibility of one or two genes of major effect acting on a polygenic-multifactorial background. ${ }^{9}$ Putative susceptibility loci have been identified using non-parametric linkage methods on chromosomes 19 and $21 . .^{1011}$

Evidence for a susceptibility locus on chromosome 19 has also come from association studies. Schellenberg et al ${ }^{12}$ reported an association between familial $\mathrm{AD}$ and the smaller allele $\left(\mathrm{A}^{2}\right)$ of a TaqI RFLP of the apolipoprotein CII gene on the long arm of chromosome 19. More recently, Roses' group have shown a strong association between the e4 allele of apolipoprotein $\mathrm{E}$ in both familial and sporadic late onset $\mathrm{AD} .{ }^{1314} \mathrm{We}$ have attempted to replicate these two findings. Although we were unable to show an association between $A D$ and the TaqI polymorphism at the Apo CII locus, we have been able to replicate the finding of a strong association between $\mathrm{AD}$ and the e4 allele of Apo E.

\section{Methods}

The patient group consisted of 95 subjects with $\mathrm{AD}$ (44 males and 51 females): 34 were obtained from the Cardiff Memory Clinic; 28 were the first sampled members of families with more than one case of late onset $\mathrm{AD}$; and 33 were recruited from local psychogeriatric hospitals. The mean age of the patient group was 73.5 years (SD 10.1) with a mean age of onset of 67.5 years (SD 9.3). The majority of patients had an age of onset greater than 65 years $(n=56)$. Patients met the NINCDS criteria for probable AD. ${ }^{15}$ An age matched control group consisting of 86 subjects was obtained from the community with the help of a local general medical practice who identified elderly non-demented persons from their practice records. Potential controls were screened with the Minimental State examination ${ }^{16}$ and included if they scored 28 or higher. The mean age of the control group was 73.2 years (SD 6.07). All patients and controls were white.

With the approval of the local ethics committee and the consent of the patient's nearest relative, a sample of venous blood, anticoagulated with EDTA, was taken and DNA extracted from the white cells by a standard procedure. Digestion of the DNA and Southern blotting were also carried out by standard procedures. The Apo CII cDNA probe used was a $440 \mathrm{bp}$ cDNA insert, ${ }^{17}$ which detects allelic fragments of $3.8 \mathrm{~kb}$ and $3.5 \mathrm{~kb}$, designated $\mathrm{A} 1$ and $\mathrm{A} 2$ respectively, after digestion with TaqI. PCR analysis of apolipoprotein E genotypes was carried out by the method of Wenham et al. ${ }^{18}$

Differences in allele and genotype frequencies were analysed by the method of Woolf. ${ }^{19}$ The observed and expected genotype frequencies were compared in order to ensure that the loci were in Hardy-Weinberg equilibrium (HWE) using a $\chi^{2}$ goodness of fit test. For the Apo E polymorphism, alleles 2 and 3 were collapsed because of small cell sizes. Haplotype frequencies were estimated according to a 
maximum likelihood procedure. ${ }^{20}$ The significance of linkage disequilibrium (D) was tested by a likelihood ratio test.

\section{Results}

APO CII ASSOCIATION STUDY

Results were obtained for 78 controls (38 males) and 89 patients (43 males) and are shown in table 1 . The frequency of the smaller $3.5 \mathrm{~kb}$ allele in the control group was 0.52 and in the patient group 0.53 . Forty seven of the patient group were known to have affected first degree relatives and, considering this subgroup, the frequency of the A2 allele was 0.57. This difference was not statistically significant $\left(\chi^{2}=1 \cdot 31, \mathrm{df}=1, \mathrm{p}=0.25\right)$. The observed distributions of genotypes were close to the values expected on the basis of Hardy-Weinberg equilibrium in both the patients $\left(\chi^{2}-0 \cdot 2\right.$, $\mathrm{df}=1, \mathrm{p}=0.65)$ and controls $\left(\chi^{2}=3 \cdot 16, \mathrm{df}=1\right.$, $\mathrm{p}=0.08$ ).

APO E ASSOCIATION STUDY

Apo E genotyping was successful in 77 controls ( 38 males) and 86 patients ( 43 males) and

Table 1 Distribution of Apo CII TaqI RFLP genotypes in $A D$ patients and age matched controls

\begin{tabular}{llll}
\hline & $A_{1} A_{1}$ & $A_{1} A_{2}$ & $A_{2} A_{2}$ \\
\hline Patients $(\mathrm{n}=89)$ & 19 & 45 & 25 \\
Controls $(\mathrm{n}=78)$ & 14 & 47 & 17 \\
\hline
\end{tabular}

Table 2 Apolipoprotein E genotype distribution in $A D$ patients and age matched controls

\begin{tabular}{lccccll}
\hline & Genotype & & & \\
\cline { 2 - 7 } & $3 / 3$ & $3 / 2$ & $3 / 4$ & $4 / 4$ & $2 / 2$ & $2 / 4$ \\
\hline Patients $(\mathrm{n}=86)$ & 38 & 6 & 25 & 16 & 1 & 0 \\
Controls $(\mathrm{n}=77)$ & 46 & 13 & 13 & 2 & 1 & 2
\end{tabular}

\section{4}

6

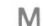

M

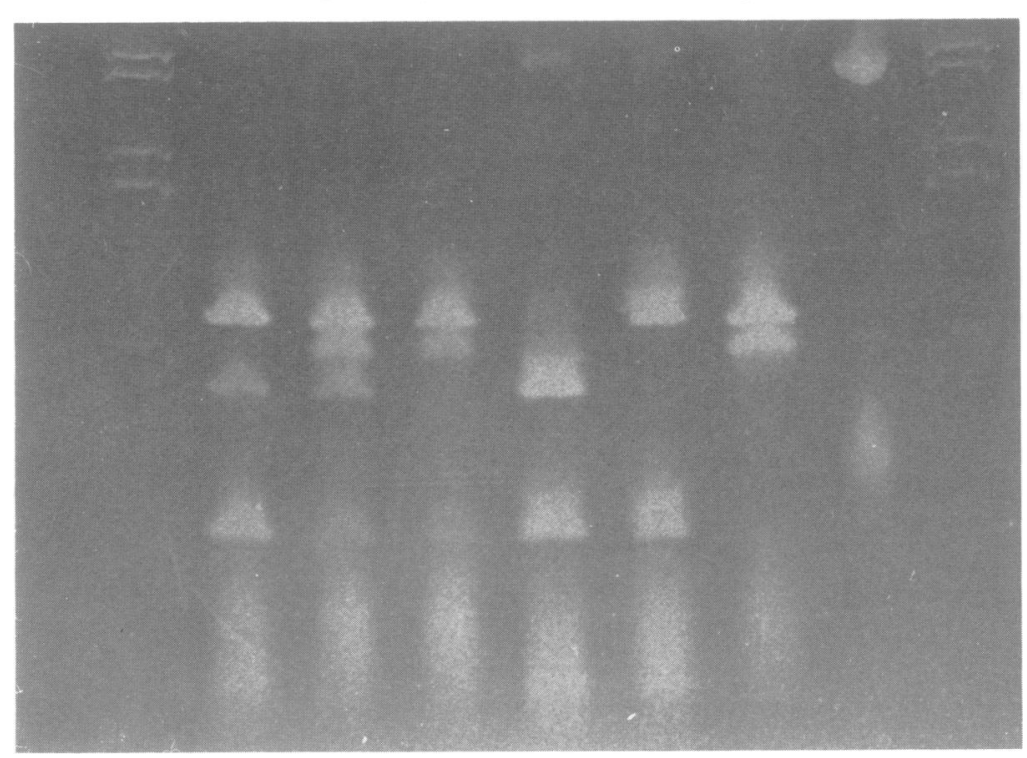

The appearance of the six possible Apo E genotypes after digestion of PCR amplified Apo E DNA with CfoI and electrophoresis through $10 \%$ polyacrylamide (after Wenham et al ${ }^{\prime 8}$ ). The tracks are identified as follows. Tracks $M, D N A$ size markers, track 1, Apo E 3/4 genotype; track 2, Apo E 2/4 genotype; track 3, 2/3 genotype; track 4, Apo E 4/4 genotype; track 5, Apo E 3/3 genotype; track 6 Apo E 2/2 genotype; track 7, undigested PCR amplified DNA. the results are shown in table 2 . The figure illustrates the appearance of the six possible Apo E genotypes after digestion of Apo E PCR products with $C f o I$ and electrophoresis through $10 \%$ polyacrylamide. In the control group the frequencies of e2 $(0 \cdot 11)$, e3 $(0 \cdot 77)$, and e4 (0.12) alleles did not differ markedly from those found previously in population surveys. ${ }^{21-23}$ In contrast, the prevalence of the e4 allele was markedly increased in the patients $(0.33)$ as compared to the control group $(0.12)$ and this was highly significant $\left(\chi^{2}=18 \cdot 4\right.$, $\mathrm{df}=1, \mathrm{p}=0.00002 ; \mathrm{OR}=3.5 ; 95 \%$ confidence interval 2-6.3. The risk of $\mathrm{AD}$ in e4 homozygotes $(\mathrm{OR}=10 \cdot 67,95 \%$ confidence interval $2 \cdot 3-48 \cdot 8)$ was greater than in e4 heterozygotes $(\mathrm{OR}=2 \cdot 22,95 \%$ confidence interval $1 \cdot 1-4 \cdot 7)$ when compared with those without the e4 allele. However, the difference between e4 homozygotes and heterozygotes did not achieve statistical significance $\left(\chi^{2}=3 \cdot 7, \mathrm{df}=1\right.$, $\mathrm{p}=0.055 ; \mathrm{OR}=4.8 ; 95 \%$ confidence interval 1-23.9). Genotype frequencies in the control group were close to those expected on the basis of HWE $\left(\chi^{2}=0.51, \mathrm{df}=1, \mathrm{p}=0.5\right)$. Significant departure from HWE was observed in the patients $\left(\chi^{2}=9.97, \mathrm{df}=1, \mathrm{p}=0.002\right)$, reflecting the relative excess of e4 homozygotes in this group.

A one way analysis of variance comparing age of onset in patients with no, one, or two copies of the e4 allele found no significant effect ( $F$ ratio $=1 \cdot 95, d f=2, p=0 \cdot 15)$. On the other hand, there appeared to be some effect of family history on the prevalence of the e4 allele, the frequency of the e 4 allele being 0.4 in the presence and 0.26 in the absence of a family history of $A D$, although this trend was not statistically significant $\left(\chi^{2}=2 \cdot 3, \mathrm{df}=1\right.$, $\mathrm{p}=0 \cdot 13$ ).

\section{LINKAGE EQUILIBRIUM BETWEEN THE APO CII} AND APO E LOCI

Using the data in table 3 it is possible to ascertain unambiguously 134 patient and 122 control Apo E-Apo CII haplotypes. In the patient group, there appears to be a slight excess of the e4 A2 haplotype, but the distribution skew was not significant at the $5 \%$ level $\left(\chi^{2}=4 \cdot 55, \mathrm{df}=2, \mathrm{p}=0 \cdot 1\right)$. There was no suggestion of linkage disequilibrium occurring in the control group $\left(\chi^{2}=1.83, \mathrm{df}=2, \mathrm{p}=0.4\right)$.

\section{Discussion}

We have replicated the original observation of Strittmatter et $a l^{13}$ of an association between

Table 3 Distribution of Apo CII (A) and Apo E (E) genotypes in $A D$ patients and controls

\begin{tabular}{|c|c|c|c|c|c|c|}
\hline \multirow{3}{*}{$\begin{array}{l}\text { Genotypes } \\
\text { Apo E }\end{array}$} & \multicolumn{3}{|c|}{ Patients } & \multicolumn{3}{|c|}{ Controls } \\
\hline & \multicolumn{6}{|c|}{ Apo CII } \\
\hline & $A_{1} A_{1}$ & $A_{1} A_{2}$ & $A_{2} A_{2}$ & $A_{1} A_{1}$ & $A_{1} A_{2}$ & $A_{2} A_{2}$ \\
\hline $\mathrm{E}_{2} \mathrm{E}_{2}$ & - & 1 & - & - & 1 & - \\
\hline $\mathrm{E}_{2} \mathrm{E}_{3}^{2}$ & 1 & 1 & 4 & 2 & 6 & 4 \\
\hline $\mathrm{E}_{2} \mathrm{E}_{4}^{3}$ & - & - & - & 1 & - & 1 \\
\hline $\mathrm{E}_{3} \mathrm{E}_{3}$ & 12 & 16 & 7 & 10 & 29 & 7 \\
\hline $\mathrm{E}_{3}^{3} \mathrm{E}_{4}^{3}$ & 3 & 11 & 7 & 1 & 8 & 3 \\
\hline $\mathrm{E}_{4} \mathrm{E}_{4}$ & 1 & 9 & 6 & - & 1 & 1 \\
\hline
\end{tabular}


the 4 allele of apolipoprotein $\mathrm{E}$ and AD. Our data also suggest that the risk of $\mathrm{AD}$ may be greater in e4 homozygotes than in heterozygotes. The frequency of the e4 allele in our patients is not as strong as in the first study $(0.33 v 0.50)$. A plausible explanation for this difference is that the cases studied by Strittmatter et $a l^{13}$ were all from multiply affected families. In contrast, our patient group, although enriched for a positive family history, contained almost $50 \%$ of apparently sporadically occurring AD. In fact, Saunders et al ${ }^{14}$ have found that the frequency of the e4 allele in probable sporadic $A D$ was 0.36 , a figure which is closer to our own. Interestingly, these workers also found that the e4 frequency in 176 cases of necropsy proven $\mathrm{AD}$ was, at 0.4 , higher than the rate for clinically diagnosed probable AD. This raises the possibility that diagnostic inaccuracy may have reduced the e4 frequency in our clinically diagnosed series. However, the trend in our data suggests that the 44 allele frequency is higher in the family history positive cases and this would be in keeping with the presumptive increase in genetic loading expected in AD kindreds.

Our failure to show an association between $\mathrm{AD}$ and the small allele of the Apo CII TaqI RFLP is at odds with the work of Schellenberg et al. ${ }^{12}$ It is possible that the increased familial loading in their sample may, in part, account for this difference. Another possibility is that there is an age effect on the allele frequency of this RFLP such that bearers of the small TaqI RFLP are more likely to reach advanced age. Thus, the fact that our control group was age matched, whereas that of Schellenberg et al was not, may explain why the frequency of the smaller allele was larger in our controls $(0.53)$ than in the earlier study $(0.39)$. Inadequate digestion of the DNA by TaqI in our study would seem to be an unlikely explanation for the differences in Apo CII TaqI RFLP allele frequencies between the two studies, since we obtain an excess of the smaller, therefore digested, restriction fragment.

The fact that we were unable to show linkage disequilibrium between alleles of the Apo CII and Apo E genes is in keeping with the later work of Houlston et al, ${ }^{24}$ although in view of the data trend in the patient group, it may well be that a larger patient series would show linkage disequilibrium between the two loci in $\mathrm{AD}$ patients.

The contribution made by apolipoprotein $\mathrm{E}$ to the pathogensis of $\mathrm{AD}$ is unclear. Of course it is logically possible that the Apo E gene merely acts as a neutral marker for some other gene with which it is in linkage disequilibrium and which predisposes to $\mathrm{AD}$. However, a number of lines of evidence point to the direct involvement of apolipoprotein $\mathrm{E}$ in the pathogenesis of AD. Like APP, it is known to be a neuronal stress protein, because its synthesis is greatly increased following injury to the nervous system. ${ }^{25-28}$ Apolipoprotein $\mathrm{E}$ has also been shown to bind to amyloid deposits in $\mathrm{AD}$ and Creutzfeld-Jakob disease, as well as to intracellular neurofibrillary tangles. ${ }^{29}$ Recent work suggests that it may facilitate the deposi- tion of A4 peptide as amyloid. Strittmatter et $a l^{13}$ have convincingly shown that apolipoprotein $\mathrm{E}$ binds avidly to synthetic A4 peptide and have gone on to show that the apolipoprotein e4 form, at physiological $\mathrm{pH}$, binds more rapidly to $\beta$ amyloid peptide than the e3 form. ${ }^{130}$ In another study Schmechel et $a l^{31}$ have shown that AD brains from patients with one or two e4 alleles have increased amyloid deposition as compared to brains from those who do not possess this allele. These findings suggest that apolipoprotein e4 might increase the rate at which amyloid deposits accumulate. If this is correct, then it is perhaps surprising that our data, and that of Saunders et al, ${ }^{14}$ do not show a relationship between e4 genotype and age of onset of AD. However, this may have occurred as a result of ascertainment biases. Indeed, a more recent study of 42 families with late onset $\mathrm{AD}^{32}$ found that mean age of onset decreased from 84 to 68 years with increasing number of e4 alleles.

Whatever the role apolipoprotein $\mathrm{E}$ plays in the pathogenesis of $\mathrm{AD}$, it seems that there is an increased prevalence of the e4 allele in patients with $\mathrm{AD}$. The prevalence may be increased further in family history positive cases. We estimate that considering the patient group as a whole, possession of the e4 allele increases the risk of $\mathrm{AD}$ by some 3.5-fold, and the relative risk in 44 homozygotes may be as high as 10 .

This work was generously supported by a grant from the Mental Health Foundation. Additional funds were provided by the Swansea and Lliw Valley branch of the Alzheimer's Disease Society. We also thank Dr M E Robinson and Mrs Barbara Society. We also thank Dr M E Robinson and Mrs Barbara collection of the control group; Professor G Wilcock, Department for the Care of the Elderly, Frenchay Hospital, Bristol, ment for the Care of the Elderly, Frenchay Hospital, Bristol,
for clinical material; and Dr Allen Roses for access to data for clinical materia
before publication.

1 Goate A, Chartier-Harlin MC, Mullan M, et al. Segregation of a missense mutation in the amyloid precurso protein gene with familial Alzheimer's disease. Nature protein gene with

2 Chartier-Harlin MC, Crawford F, Houlden H, et al. Early onset Alzheimer's disease caused by mutations at codon 717 of the $\beta$-amyloid precursor protein gene. Nature 1991;353:844-6.

3 Murrell J, Farlow M, Ghetti B, et al. A mutation in the amyloid precursor protein associated with hereditary $\mathrm{Alz}$ heimer's disease. Science 1991;254:97-9.

4 Mullan M, Crawford F, Axelman K, et al. A pathogenic mutation for probable Alzheimer's disease in the amyloid precursor protein gene at the $\mathrm{N}$ terminus of $\beta$-amyloid. Nature Genet 1992;2:245-7.

5 Schellenberg GD, Bird TD, Wijsman EM, et al. Genetic linkage evidence for a familial Alzheimer's disease locus on chromosome 14. Science 1992;258:668-71.

6 St George-Hyslop PH, Haines JL, Rogaev E, et al. Genetic evidence for a novel familial Alzheimer's disease locus on chromosome 14. Nature Genet 1992;2:330-4.

7 Van Broeckhoven C, Backhovens H, Cruts M, et al. Mapping of a gene predisposing to early-onset Alzheimer's ping of a gene predisposing to early-onset Alzheimer's disease to $1992 ; 2: 335-9$.

8 Mullan M, Houlden $\mathrm{H}$, Windelspecht $\mathrm{M}$, et al. A locus for familial early onset Alzheimer's disease on the long arm of chromosome 14, proximal to alpha 1-antichymotrypsin. Nature Genet 1992;1:245-7.

9 Farrer LA, Myers RH, Connor L, et al. Segregation analysis reveals evidence of a major gene for Alzheimer disease. Am 7 Hum Genet 1991;48:1026-33.

10 Pericak-Vance MA, Bebout JL, Gaskell PC, et al. Linkage studies in familial Alzheimer disease: evidence for chromosome 19 linkage. Am 7 Hum Genet 1991;48:1034-50.

11 Heston LL, Orr HT, Rich SS, et al. Linkage of an Alzheimers' disease susceptibility locus to markers on human chromosome 21 . Am $\mathcal{J}$ Med Genet 1991;40:449-53.

12 Schellenberg GD, Boehnke JL, Wijsman EM, et al. Genetic association and linkage analysis of the apolipoprotein CII locus and familial Alzheimer's disease. Ann Neurol 1992;31:223-7.

13 Strittmatter WJ, Saunders AM, Schmechel D, et al. Apolipoprotein $\mathrm{E}$ : high avidity binding to beta-amyloid and increased frequency of type 4 allele in late onset familial 
Alzheimer disease. Proc Natl Acad Sci USA 1993;90:1977-81.

14 Saunders AM, Strittmatter WJ, Schmechel D, et al. Association of apolipoprotein E allele e4 with late-onset familial and sporadic

15 McKhann G, Drachman D, Folstein M, et al. Clinical diagnosis of Alzheimer's disease: report of the NINCDSADRDA work group under the auspices of department of health and human services task force on Alzheimer's disease. Neurology 1984;34:939-44.

16. Folstein MF, Folstein SE, McHugh PR. 'Mini-Mental State': a practical method for grading the cognitive state of patients for the clinician. $\mathcal{f}$ Psychiatr Res 1975;12:18998.

17 Myklebost O, Royne S. A physical map of the apolipoprotein gene cluster on human chromosome 19. Hum Genet 1988;78:244-7.

18 Wenham PR, Price WH, Blundell G, et al. Apolipoprotein E genotyping by one-stage PCR Lancet 1991;337:1158-9.

19 Woolf $\mathrm{B}$. On estimating the relation between blood group and disease. Ann Hum Genet 1955;19:252-3.

20 Hill WG. Estimation of linkage disequilibrium in randomly mating populations. Heredity 1974;33:229-39.

21 Mahley RW. Apolipoprotein E: cholesterol transport with expanding role in cell biology. Science 1988;240:622-30. 22 Menzel HH, Kladetzky R, Assmann G. Apolipoprotein E polymorphism and coronary artery disease. Arteriosclerosis 1983;3:310-15.

23 Cauley JA, Eichner JE, Kamboh $\mathrm{M}$, et al. Apo $\mathrm{E}$ allele frequencies in younger (age 42-50) vs older (65-90) women. Genet Epidemiol 1993;10:27-34.

24 Houlston RS, Snowden C, Green KGMM, et al. Apolipoprotein (apo) E genotypes by polymerase chain reaction and allele specific oligonucleotide probes: no detectable linkage disequilibrium between apo $\mathrm{E}$ and apo $\mathrm{CII}$. Hum Genet 1989;83:364-8.

25 Ignatius MJ, Gebicke-Harter PJ, Pate Skene JH, et al. Expression of apolipoprotein E during nerve degenera Expression of apolipoprotein E during nerve degeneration and regener

26 Snipes GJ, McGuire CB, Norden JJ, et al. Nerve injury stimulates the secretion of apolipoprotein $\mathrm{E}$ by nonneuronal cells. Proc Natl Acad Sci USA 1986;83:1130-4.

27 Boyles JK, Zoellner CD, Anderson LJ, et al. A role for apolipoprotein E, apolipoprotein $\mathrm{A}-1$, and low density lipoprotein receptors in cholesterol transport during regeneration and remyelination of the rat sciatic nerve. $₹$ Clin Invest 1989;83:1015-31.

28 Hardy J, Allsop D. Amyloid deposition as the central event Trends Pharmacol $S$ 1991;12:383-8.

29 Nambay Y, Tomonaga M, Kawasaki H, et al. Apolipoprotein $\mathrm{E}$ immunoreactivity in cerebral amyloid deposits and neurofibrillary tangles in Alzheimer's disease and Kuru plaque amyloid in Creutzfeldt-Jakob disease. Brain Res
1991;541:163-6.

30 Strittmatter WJ, Weisgraber $\mathrm{KH}$, Huang $\mathrm{D}$, et al. Binding of human apolipoprotein $\mathrm{E}$ to synthetic amyloid $\beta$-pepato for lateonset Alzheimer disease. Proc Natl Acad Sci USA

31 Schmechel DE, Saunders AM, Strittmatter WJ, et al. Increased amyloid $\beta$-peptide deposition in cerebral cortex as a consequence of apolipoprotein $\mathrm{E}$ genotype in lateonset Alzheimer's disease. Proc Natl Acad Sci USA 1993;90:9649-53.

32 Corder EH, Saunders AM, Strittmatter WJ, et al. Apolipoprotein E4 gene dose and the risk of Alzheimer disease in late onset families. Science 1993;261:921-3. 